\title{
City Rankings and the Citizens: Exposing Representational and Participatory Gaps
}

\author{
Ana Duarte Melo ${ }^{(凶)}(\mathbb{D}$ \\ Communication and Society Research Centre, University of Minho, Braga, Portugal \\ anamelo@ics.uminho.pt
}

\begin{abstract}
A critical reflection on the purposes, role and performance of city rankings through an holistic communicational approach is at the core of this article. Grounded on a conceptual framework that highlights the contemporary idea of the city-beyond the smart city and more as a co-intelligent, collaborative and co-creative entity, and on the performance outputs of city rankings as territorial and strategic communication tools that actually represent the state of cities, we address the citizens' presence or contribute-as main city stakeholders-to city rankings. In order to make research tangible with a practical component, an exploratory comparative content analysis of three recognized city rankings: the CBI - City Brands Index 2017, the GCR - 2018 Global Cities Report, and the Global Liveability Index 2018-was carried out.

Conclusive notes argue that in order to effectively represent cities, as they are lived, thought and built by their citizens in their everyday, city rankings must rely in more real-time, updated, people's perception centred data, and embed more citizen participation and insights. Moreover, methodology transparency and accountability should be promoted in order to add trust value to city rankings.
\end{abstract}

Keywords: City rankings · Communication $\cdot$ Citizenship $\cdot$ Participation

\section{Introduction}

A communicational approach to territories is in order when we address the process of building "smart and liveable cities". The main insight of this article intends to reflect on how territories, particularly cities, engage in communication and on how communication-namely through city rankings, contributes (or not) to better cities. We will focus our attention in particular on city rankings as tools for gauging what is relevant in a city, but also as central communication tools in building the city's image, reputation and representation, that is, in adding symbolic and narrative value to the city. Our perspective draws on the idea of the city made by and for the citizens, a city as the communal capital and knowledge, a smart city that serves, includes and drives the collective. Therefore, the main question we intend to address could be summarized in a straightforward interrogation: do city rankings take the citizens into account through participatory practices? 
To assess this, we will analyse a number of city rankings and map some of its constitutive criteria that allegedly include citizens' inputs, whether through direct or indirect participatory practices. Furthermore, we will reflect critically on the use of city rankings as territorial communication management tools, namely on their strategic and managerial value. To set a framework to this research a diversity of notions is summoned, namely, the ideas of city, citizens and participation as constitutive parts of the city, the concepts of smart city, co-intelligent territory, territorial communication management, city brands, image and reputation. We consider them nuclear to understand the subject of city rankings.

What is a city and what does it mean? And how do city rankings contribute to construct that meaning and add value to the city?

\section{A Conceptual Framework}

\subsection{From the Smart City to the Co-intelligent Territory}

The smart city concept emerged in the 1990s, associated with the application of information and communication technologies to cities, therefore embedded within an intelligence framework, whether technology, human, institutional, energy, or data management centred just to name a few. Two main approaches can be found related to smart cities: (1) a management approach, focused on efficiency, resources and flows, crossing a number of areas: energy, mobility, transport, consumption, waste disposal, environmental impact, etc.; and (2) a social innovation approach, in which smart cities improve the lives of citizens and visitors: a smart city collects data from citizens, devices and assets to interact directly with both the community and the city infrastructure; optimize city operations and performance, services and interaction with citizens.

"There is a range of definitions of a smart city, but the consensus is that smart cities utilize IoT sensors, actuators, and technology to connect components across the city. This connects every layer of a city, from the air to the street to underground. It's when you can derive data from everything that is connected and utilize it to improve the lives of citizens and improve communication between citizens and the government that a city becomes a smart city" (Maddox 2018).

As recent as it is, the smart city is a work-in-progress concept, prone to discussion and criticism (Cardullo and Kitchin 2019; Hollands 2008; Rizzon et al. 2017). Hollands (2008) proposes a "preliminary critical polemic" in an effort to clear "[smart cities] definitional impreciseness, numerous unspoken assumptions and a rather selfcongratulatory tendency (what city does not want to be smart or intelligent?)" (Hollands 2008, p. 304). The smart city concept involves both an operational, managerial insight and a philosophical and holistic approach to the city (Vanolo 2014).

Several designations emerged that point towards a general definition of what a smart city is: "Intelligent (...) Digital (...) Sustainable (...) Technocity (...) Well-being city" (Dameri 2013, p. 2546); or, in a more dynamic perspective, integrating the notion of change and transformation: "In today's modern urban context, we appear to be constantly bombarded with a wide range of new city discourses like smart, intelligent, 
innovative, wired, digital, creative, and cultural, which often link together technological informational transformations with economic, political and socio-cultural change" (Hollands 2008, p. 305).

According to Marsal-Llacuna, Colomer-Llinàs and Meléndez-Frigola, "Smart Cities have evolved out of livable, creative, digital and knowledge cities, drawing heavily on the concept of the Sustainable City and having in common a large technological component" (Marsal-Llacuna et al. 2015, pp. 617-618).

Smart cities' critique frequently deals with opposing perspectives, namely techno centred $v s$ citizen centred or the private interest $v s$ public interest; or long term effects and objectives, namely sustainability (Martin et al. 2018); ethical issues such as privacy (Zhang et al. 2019), big data; freedom (Vanolo 2014) or participation (Cardullo and Kitchin 2019). Many of these critical perspectives converge on an essential question: what does it mean to be a citizen in a city, i.e. what does it mean to be a smart citizen in a smart city?

Maddox (2018) highlights smart cities' progress and perspectives, "Smart cities are more than a trend - they're the wave of the future because the world is becoming more urban, with $60 \%$ of the population expected to live in cities by 2050" (Maddox 2018) and proposes a comprehensive guide to what a smart city is, concluding with a provocative statement: "A truly smart city improves the quality of life for citizens and visitors, and while a smart city can be many things, just as with humans, some are smarter than others" (Maddox 2018).

In a comprehensive proposal Dameri (2013) establishes structural elements, namely, territory, technology, citizens and government as components, and environmental sustainability, quality of life and well being, participation, knowledge and intellectual capital, as objectives of the smart city concept.

Chourabi et al. (2012) identified eight critical factors of smart city initiatives: management and organization, technology, governance, policy context, people and communities, economy, built infrastructure, and natural environment.

In a previous research we proposed a broader insight (Melo 2019), inspired on Tom Atlee's concept of co-intelligence (Atlee 2012, 2014, 2017), to approach territorial "smartness", one based on systematic communicative engagement within the city's stakeholders: "There is no smart territory without smart communication. There is no smart territory without smart citizens who share the vision, essence, projects and planning of territories." (Melo 2019, p. 247). In this article we will focus further on the participation area of Dameri's and on Chourabi's fifth factor-people and communities - as constitutive structural elements of the smart city. This perspective coincides with the conclusions of Hollands (2008) that, to a certain extend, expose the smart city as an impediment in itself:

"In essence the smart progressive city needs and requires the input and contribution of these various groups of people, and cannot simply be labelled as smart by adopting a sophisticated information technology infra-structure or through creating selfpromotional websites. Cities are more than just wires and cables, smart offices, trendy bars and luxury hotels, and the vast number of people who live in cities deserve more than just these things. Because the smart city label can work to ideologically mask the nature of some of the underlying changes in cities, it may be a partial impediment toward 
progressive urban change. Real smart cities will actually have to take much greater risks with technology, devolve power, tackle inequalities and redefine what they mean by smart itself, if they want to retain such a lofty title" (Hollands 2008, p. 316).

In fact, collective intelligence is not a new concept. It has been studied more consistently after the 1980's. Stremtan (2008) wrapped up a definition based on diverse theoretical perspectives: "Collective intelligence is intelligence that emerges from the collaboration and competition of many individuals (...) appears in a wide variety of forms of consensus decision making $(. .$.$) is the intelligence of connections, of rela-$ tions (...) These connections induce co-operations, which constitute materialization of collective intelligence (Stremtan 2008, p. 10)".

Furthermore, the author refers to collective intelligence as "the capacity of an organization, of a collective to ask questions and to seek the answers together" (Stremtan 2008 , p. 10). Concurrently, Tom Atlee's proposes a holistic, inclusive perspective of what co-intelligence is: "intelligence that takes wholeness, interconnectedness, co-creativity and participation seriously. Co-intelligence is collective, collaborative, synergistic, wise, empathic, heartful, and connected to greater sources of intelligence. It is often marked by how creatively it uses dissonance and diversity." (Atlee 2017, pp. 80-81). Therefore, a co-intelligent city would be grounded on democratic participatory practices, oriented by public wisdom and citizen-led politics and driven by social activism.

These visions, based in interconnectedness and participation, seem crucial to frame both the managerial and the communicative approaches-inspired in participatory and community communication-to territories in the contemporary.

Moreover, discussions on the concept of the city and the right to the city point towards a similar direction: a smart city is a communicative city. And is mostly defined by its citizens.

"The terms global city, smart city, connected city, sustainable city, inclusive city, and green city all encapsulate the collective value placed on a location where many people live and work. All these terms are both descriptive and normative of a reality based upon a gathering of people located in close proximity. A city consists of structures and services, but a city without people is simply an inanimate shell-a dead space. People and their needs define a city" (Drucker and Gumpert 2016, p. 1366).

\subsection{Territorial Communication and City Rankings}

Braga has currently about 181,000 inhabitants, with $57.8 \%$ of the population aged Territorial communication is intrinsic to the city's definition. Through communication the city as to think, project and question it-self on what it wants to communicate, how it wants to be perceived, why and what it wants to communicate. This is essentially strategic thinking, transversal throughout the communication interaction in the construction of the city's brand, image, reputation and symbolic value (Kavaratzis 2019; Kavaratzis and Kalandides 2015; Melo 2018, 2019; Papp-Váry 2011), hence, in the construction of its own identity (Anholt 2007; Ingenhoff et al. 2019).

"Besides the material capabilities of cities, how well they are able to brand themselves plays a large part in their success. The number of tourists, investors, new inhabitants, or the products of the city depend on the success of this self-branding. It also affects the locals and their sense of pride and contentment living in the city. Fortunately for cities, 
more and more brand models and rankings are available to assess their standing among others in respect to image and to reveal their comparative shortcomings" (Papp-Váry 2011, p. 555).

Territory provides a rich field for research, summoning a diversity of perspectives, including geography, public diplomacy, business and management, social psychology, sociology, urbanism and planning, political communication and communication science, demanding a transdisciplinary approach (Buhmann et al. 2019).

Territorial communication models have been developed and refined to serve the strategic communication of places (Anholt 2007; Buhmann et al. 2019; Kavaratzis 2019; Papp-Váry 2011). The most popular and recognized territorial communication model is certainly Simon Anholt's hexagon. This seminal model created to frame nation-brand communication was later adapted to cities. Also known as de "P's model" is based on five categories: Presence, Place, Pre-requisites, People, Pulse and Potential (Kirchener 2018, p. 2). Such models serve as inspiration for the setting of territorial indexes although open to systematic improvement, as "the challenges of combining the appeal of a holistic approach (...) with the necessity of specific measurement tools have not as yet been solved" (Merkelsen and Rasmussen 2019, p. 81).

Territorial rankings have been established-and used-for a number of reasons, assessment and competiveness being the most obvious ones (Drucker and Gumpert 2016; Merkelsen and Rasmussen 2019; Newburry and Song 2019). They are part of the strategic ammunition territorial managers, communication experts, politicians, urban planners and decision makers in general use to promote, enhance and add value to their nations, regions and cities. They use it to assess territories attractiveness-both theirs and their competitors, thus promoting territorial competitiveness (Chourabi et al. 2012; Giffinger et al. 2010), motivating and rewarding their teams performance, and establishing tangible strategic objectives.

Referring to nation branding attraction conditions, Merkelsen and Rasmussen argue that indexes "serve as catalyst for creating these conditions" (Merkelsen and Rasmussen 2019, p. 77) and they specify three: "a reputational logic (...) a state of competition (...) a simple solution to a complex challenge" (Merkelsen and Rasmussen 2019, pp. 7779). They conclude by noticing the paradox that what "renders the nation brands index inappropriate as a tool for governments is the exact same quality that makes these rankings attractive to them" (Merkelsen and Rasmussen 2019, p. 81). These paradoxical characteristics seem to fit also the case of city indexes.

There are all types of rankings highlighting economic features, assessing developing metrics, cultural drivers, wellbeing, happiness, participation, transparency, governance and sustainability (Cabannes 2019; McArthur and Robin 2019; Meijering et al. 2014; Okulicz-Kozaryn 2013; Yigitcanlar and Inkinen 2019).

"The proliferation of criteria has led to the propagation of rankings and award programs allowing cities to proudly advertise their recognition as: livable, clean, large, sustainable, green, healthy, and slow. Awards recognize projects, vision, design, and research" (Drucker and Gumpert 2016, p. 1369).

Giving a meaning to data seems to be one of the outcomes and objectives of territorial rankings. Although some criteria might be fairly clear and objective such as the existence of a public transport network or public health care, other criteria such as the level of 
censorship or corruption might be more difficult to grasp. If aggregating data might be useful to understand some metrics, disaggregating them is frequently the fastest track to understand how narratives around territories are directed, i.e., if a city ranks good in a public health network assessment, does not mean that there is actual access from the population to that resource. Thus, when assessing a ranking, is important to mine the sources, the methods and interpretations offered to that data.

Marsal-Llacuna, Colomer-Llinàs and Meléndez-Frigola focused their work on establishing a set of criteria assembled in "a synthetic indicator to summarize a city's "intelligence" or "smartness"” (Marsal-Llacuna et al. 2015, p. 612). They draw attention towards the need to have physical and non-physical urban data, as much real time as possible, and highlight the need to produce comparable indicators with other rankings. More specifically, the authors insist on the "the need for an "intelligent index" to monitor the Smart Cities initiative" (Marsal-Llacuna et al. 2015, p. 620).

Rankings themselves are object of rating. The Branding Institute CMR, set up a methodology to evaluate rankings based on four criteria: "Relevance \& Impact of Ranking; Added Value \& Insights of Ranking; Trustworthiness \& Intention of Ranking provider and media outlet and Methodology of Ranking" (Casanova et al. 2018).

Nevertheless, being commonly accepted as communication tools central to reputation and image management, territorial rankings have been criticized for being prone to instrumentalization and manipulation. Indexes are "more rhetorical than scientific as they primarily serve purposes of legitimization and persuasion" (Merkelsen and Rasmussen 2019 , p. 80). Critique draws mostly on the fact that rankings are both being data driven vs people driven, elitist vs communal- "City rankings are a window onto the projected tastes of a highly specific elite" (O' Sullivan 2019), promoting mainly private interests instead of territorial ones, thus not representing the real life of the city: "it seems mistaken to present all cities as simple clusters of amenities, not when access to them is being subtly discouraged by broader social trends or actively denied to certain groups" (O'Sullivan 2019).

With a provocative tittle-“"The Top 6 Reasons to Be Wary of City Rankings, Ranked"-Aarian Marshall draws attention to the controversial and unavoidable issues surrounding the topic of territorial rankings: "Different rankings measure totally different things. (...) Not all cities were included. (...) Some rankings measure reputation-not reality. (...) Some data is hard to find ... (...) ... While some data is just silly. (...) They're probably trying to sell you something" (Marshall 2015). These factors seem to set a sound starting point to inspire further research.

\section{Research and Methodological Approach}

Nowadays, school buses are seen as an innovative, sustainable alternative in urban Following the above considerations, conceptual framing and state of the art on the subject of territorial rankings a concern emerged: Are citizens represented and participating in city rankings? What is their role in the construction of city rankings narratives?

To find possible answers to this main research question, we set the following objectives: to map scoring and categories in city rankings; to identify eventual citizen representational and/or participatory criteria; to critically reflect on city rankings purposes, meanings and objectives. 
The methodology used is qualitative and relies on hermeneutical interpretation and content analysis of three recognised city rankings: City Brands Index 2017 (CBI), 2018 Global Cities Report (GCR), and Global Liveability Index 2018 (GLI).

The choice of these rankings was determined by notoriety on the Google research engine, but also by updating, access, availability and relevance. CBI - City Brands Index 2017 is an iconic city ranking, heir of the first incursions in territorial communication models, GCR - 2018 Global Cities Report, was selected for its broad scope and Global Liveability Index 2018 in order to include liveability criteria to the research, in an effort to eventually better representing citizens' insights on the cities.

The content analysis focused on the explicit categories published by each ranking to frame the data collected. Methodological explanation and transparency was also taken into account.

\section{Results and Discussion}

The three selected city rankings content was scrutinized in order to comparatively assess: the scope and methodology used; the cities that reached the top 10 scores, the categories proposed by these rankings to assemble data in a meaning making narrative, and the representation/participation of citizens.

\subsection{The Rankings: Scope and Methodology}

The CBI - City Brands Index 2017 is also identified as the "Anholt-GfK City Brands IndexSM (CBISM)". This index inherits the knowledge work ground of Simon Anholt's-both the Nation Brands Index and the City Brands Index were pioneering in 2005, "is run once every two years and measures the image of 50 cities" (Kirchener 2018 , p. 3) and is published by GfK - Growth from Knowledge, a consultancy and market research company. Data was collected from 20 September to 3 October 2017 through " 5,057 interviews across 10 countries (Australia, Brazil, China, France, Germany, India, Russia, South Korea, UK, and USA), with at least 500 interviews per country (...) The achieved sample in each country is weighted to reflect key demographic characteristics including age, gender, and education of the online population in that country" (Kirchener 2018, p. 3).

Six key dimensions are taken into account to rank cities in this index: "Presence (the city's international status and standing); Place (its physical outdoors aspect and transport); Prerequisites (basic requirements, such as affordable accommodations and the standard of public amenities); People (friendliness, cultural diversity, how safe one feels); Pulse (interesting things to do); Potential (the economic and educational opportunities available)" (Kirchener 2018, p. 2).

Results indicate the following ranking for the first 10 places: Paris, London, Sydney, New York, Los Angeles, Rome, Melbourne, Amsterdam, San Francisco and Berlin (Table 2). Nevertheless, links were provided to further contacts and information about the CBI - City Brands Index 2017, the index itself was not available, and the information provided was public only through press releases (Kirchener, 2018). People's insights (from 10 countries) are taken into account. 
The GCR - 2018 Global Cities Report, published by A.T. Kearny, an American consultancy firm, "highlights regional trends revealed over the past decade and examines what defines the world's most influential cities" (Peterson et al. 2018, p. 1). It was established in 2008 assessing the performance of 60 cities. Based on the accumulated experience it position itself as going "beyond ranking cities (...) reveals which global cities are primed for urban transformation and growth" (Peterson et al. 2018, p. 1), exposing trends that indicate that nevertheless business activity, economics, information exchange and governance remain important criteria to score some points in the ranking, "human capital and cultural experience are also significant drivers of growth" (Peterson et al. 2018, p. 2).

The results are divided in two comparative strengths reports: the Global Cities Index, based on performance, and the Global Cities Outlook, based on potential. For this research we will take into account exclusively the Global Cities Index, centred in the current performance of cities.

This index analyses 135 cities worldwide, covering Africa (13), Asia Pacific (44), Europe (24), Latin America (15), North America (16) and Middle East (13). 27 variables grouped into a set of 5 weighted categories are considered to narrow the ranking score: "Business activity (capital flow market dynamics and major companies present); Human capital (education levels); Information exchange (access to information through internet and other media sources); Cultural experience (access to major sport events, museums, and other expos); Political engagement (political events, think tanks, and embassies)" (Peterson et al. 2018, p. 12). The first 10 cities (Table 2) in this ranking are: New York, London, Paris, Tokyo, Hong Kong, Los Angeles, Singapore, Chicago, Beijing, Brussels (Peterson et al. 2018, p. 13).

Methodology is explained in rather brief traits, more centred on how information is assembled and organised than on how it is actually collected, stating that "sources are derived from publicly available data" (Peterson et al. 2018, p. 12) and eventually substituted by country data if city data is not available.

The Global Liveability Index 2018, published by The Economist Intelligence Unit, states: "The concept of liveability is simple: it assesses which locations around the world provide the best or the worst living conditions. Assessing liveability has a broad range of uses, from benchmarking perceptions of development levels to assigning a hardship allowance as part of expatriate relocation packages" (EIU 2018, p. 7).

To find the most liveable cities of the world The Economist team analysed a number of complex variables (30) of 140 cities and aggregated them in 5 major metrics: stability, healthcare, culture and environment, education, and infrastructure (Abadi 2018).

Methodological processes are available and an explanatory chapter exposes how the rating is calculated, "For quantitative variables, a rating is calculated based on the relative performance of a location using external data sources" (EIU 2018, p. 8). However, the fact that "For qualitative variables, an "EIU rating" is awarded based on the judgment of in-house expert country analysts and a field correspondent based in each city" (EIU 2018, p. 8) reveals that the qualitative insight of this index is subject to personal sensibilities, however informed they may be, which may rise some concern over the credibility and impartiality of this kind of value judgment. 
According to this index, the 10 most liveable cities in 2018 were Vienna, Melbourne, Osaka, Calgary, Sidney, Vancouver, Toronto, Tokyo, Copenhagen and Adelaide (Table 2).

Not surprisingly, some conclusions of the report account for "a correlation between the types of cities that sit at the very top of the ranking. Those that score best tend to be mid-sized cities in wealthier countries. Several cities in the top ten also have relatively low population density (...) foster a range of recreational activities without leading to high crime levels or overburdened infrastructure" (EIU 2018, p. 4). In parallel the index draws attention to the victims of success, "The "big city buzz" that they enjoy can overstretch infrastructure and cause higher crime rates. New York (57th), London (48th) and Paris (19th) are all prestigious hubs with a wealth of recreational activities, but all suffer from higher levels of crime, congestion and public transport problems than are deemed comfortable" (EIU 2018, p. 4). Nevertheless they seem to keep their attraction factor. "The question is how much wages, the cost of living and personal taste for a location can offset liveability factors" (EIU 2018, p. 4).

Comparatively, GCR - Global Cities Report 2018 (GCR) and The Global Liveability Index 2018 (GLI) cover an approximate number of cities worldwide, while CBI - City Brands Index 2017 (CBI) covers only 50 cities (Table 1). However, CBI is based on a qualitative assessment through online interviews intended to assess "the image" of the cities, whether GCR is grounded on publicly available data on 27 metrics and GLI uses a mixed methodology, based on quantitative data and qualitative assessment of experts (Table 1).

Table 1. City rankings' scope/method comparative analysis.

\begin{tabular}{|c|c|c|}
\hline Publisher & Scope & Method \\
\hline \multicolumn{3}{|l|}{ CBI - City Brands Index 2017} \\
\hline Anholt-GfK & 50 cities & $\begin{array}{l}5,057 \text { online interviews in } 10 \text { countries; } \\
\text { sample to reflect demographic reality }\end{array}$ \\
\hline \multicolumn{3}{|l|}{ GCR - Global Cities Report 2018} \\
\hline ATKearny & 135 cities & Publicly available city data; 27 metrics; \\
\hline \multicolumn{3}{|l|}{ The Global Liveability Index 2018} \\
\hline The Economist Intelligent Unit & 140 cities & 30 qualitative and quantitative metrics \\
\hline
\end{tabular}

\subsection{The Cities}

An overview of the cities ranked in the top 10 positions in the different rankings analysed in this research reflect a diversity of assessments, exposing that the best city images, the best city performances and the most liveable cities in the world do not necessarily match (Table 2).

Actually, there is not any city that occupies one of the 10 top positions in all the three rankings. The best possible match appears to be London (number 2 in two rankings); present in two rankings but in diverse positions stand six cities (Los Angeles, 
Melbourne, New York, Paris, Sydney, Tokyo); and present in only one ranking are 16 cities (Adelaide, Amsterdam, Beijing, Berlin, Brussels, Calgary, Chicago, Copenhagen, Hong Kong, Osaka, Rome, San Francisco, Singapore, Toronto, Vancouver, Vienna).

There seems to be a prevalence of big cities, geographically concentrated in Europe (8), North America (7) and Asia-Pacific (7).

Table 2. City rankings' top 10 cities comparative analysis

\begin{tabular}{l|l|l}
\hline $\begin{array}{l}\text { 2017 CBI - City Brands } \\
\text { Index }\end{array}$ & $\begin{array}{l}\text { 2018 GCR - Global Cities } \\
\text { Report }\end{array}$ & $\begin{array}{l}\text { The Global Liveability } \\
\text { Index } 2018\end{array}$ \\
\hline 1. Paris & 1. New York & 1. Vienna \\
2. London & 2. London & 2. Melbourne \\
3. Sydney & 3. Paris & 3. Osaka \\
4. New York & 4. Tokyo & 4. Calgary \\
5. Los Angeles & 5. Hong Kong & 5. Sidney \\
6. Rome & 6. Los Angeles & 6. Vancouver \\
7. Melbourne & 7. Singapore & 7. Toronto \\
8. Amsterdam & 8. Chicago & 8. Tokyo \\
9. San Francisco & 9. Beijing & 9. Copenhagen \\
10. Berlin & 10. Brussels & 10. Adelaide \\
\hline
\end{tabular}

Concerning city image (CBI), Europe gets the most (5), followed by North America (3) and Asia-Pacific (2). The most performative cities (GCR) are mainly in Asia-Pacific (4), followed ex-aequo by Europe (3) and North America (3). Regarding the best cities to live (GLI), Asia-Pacific seems to offer more (5), followed by North America (3) and Europe (2).

\subsection{The Categories}

Analysing comparatively the city rankings' content is an attempt to find patterns that might produce further knowledge. Therefore, in this case, we will try to categorise the city rankings' categories.

A general overview portrays an apparent mismatch of the three city rankings at stake, pulverized in a diversified set of categories (Table 3 ).

CBI presents data on the image of 50 cities aggregated in presence, place, prerequisites, people, pulse and potential. Since it is based on interviews it reflects the perceptions people have on cities, whether they live there, visited the cities or not. To a certain extend it is a ranking of impressions that were constructed by direct experience, by the media, by cultural acknowledgement of the place and forged through accumulated reputational capital.

GCR reflects a mix of business activity, human capital, information exchange, cultural experience, and political engagement, whereas GLI categorises cities over stability, healthcare, culture and environment, education, infrastructure. 
The first layer of analysis exposes two sets of categories: tangible—such as "business activity", "infrastructure" or "information exchange"-and intangible—such as "pulse" or "potential".

In a second layer we can find some common concepts or words that might qualify as categories. For example: culture, education, economics, environment, health or politics. They all seem important factors to assess a city.

The analysis gets more complex when we try to understand more deeply the semantics of these categories. What does "stability", "pulse" or "political engagement" mean? A "steady job"? The "vibe of economic growth"? The "activist output" of a city? According to the research, stability is the "prevalence of petty and/or violent crime; threat of terror, military conflict and/or of civil unrest/conflict"(GLI); pulse are "interesting things to do" (CBI) on a city and political engagement includes "political events, think tanks, and embassies" (GCR).

The examples above, exploratory as they are, expose the assumption that although categories are useful to aggregate data and produce a narrative, they but might be misleading to understand data and, without proper contextualisation, may mean literally anything.

Categories are a form of simplification and aggregation of complex data in order to make it intelligible, usable and meaningful. From all parameters of the present research this is the one where the strategic intentions of the city ranking producers might be more evident, as setting categories is an immediate form of interpreting reality, and therefore an attempt to control it.

Categories and the selection of criteria they entail are also indexed to the agenda setting of city rankings production. The case of GLI is quite illustrative. Published by The Economist Intelligent Unit is promoted as a Global Liveability City Index but was designed as a tool "to help companies decide how much "hardship" allowance they would need to pay employees who relocate (...) focuses on things that matter to expats, not citizens" (Rozek et al. 2018). But this is not a hidden agenda. The GLI explains that "assessing liveability has a broad range of uses, from benchmarking perceptions of development levels to assigning a hardship allowance as part of expatriate relocation packages (...) quantifies the challenges that might be presented to an individual's lifestyle in any given location, and allows for direct comparison between locations" (EIU 2018, p. 7). Nevertheless, widespread short versions of the city index, namely as catchy titles in media about new winners and losers (McArthur and Robin 2019), frequently make this agenda invisible, adding up to other critics, on lack of transparency: "It appears that, beyond the well-designed league tables and flurry of media attention, The Economist's Global Liveability Index is a mostly subjective rating with opaque methods for comparing cities (Rozek et al. 2018).

Therefore, to fully understand what a city ranking stands for, it is crucial to go deep into strategic and methodological explanations (when and if they are available).

\subsection{The Citizen Representation/Participation}

The issue of citizen representation and participation poses methodological challenges. Not only due to the above-mentioned difficulties on tracking data collecting processes and sources, but also due to the fact that citizens are embedded in the notion of the city. 
Table 3. City rankings' categories comparative analysis.

Categories

CBI - City Brands Index 2017

- Presence (the city's international status and standing);

- Place (its physical outdoors aspect and transport);

- Pre-requisites (basic requirements, such as affordable accommodations and the standard of public amenities);

- People (friendliness, cultural diversity, how safe one feels);

- Pulse (interesting things to do);

- Potential (the economic and educational opportunities available)

GCR - Global Cities Report 2018

- Business activity (capital flow market dynamics and major companies present)

- Human capital (education levels)

- Information exchange (access to information through internet and other media sources)

- Cultural experience (access to major sport events, museums, and other expos)

- Political engagement (political events, think tanks, and embassies)

The Global Liveability Index 2018

- Stability (prevalence of petty and/or violent crime; threat of terror, military conflict and/or of civil unrest/conflict)

- Healthcare (availability and quality of private/public healthcare; availability of over-the-counter drugs; general healthcare indicators)

- Culture and environment (humidity/temperature rating; discomfort of climate to travellers; level of corruption and censorship; social or religious restrictions; sporting and cultural availability; food \& drink; consumer goods \& services

- Education (availability and quality of private education; public education indicators)

- Infrastructure (quality of road network, public transport; international links; energy provision; energy and water provision; and telecommunications; availability of good quality housing)

In the comparative analysis of the three city indexes is possible to observe indirect and direct representation and participation of citizens.

We would consider indirect representation/participation are present in variables related with citizens' actions and behaviours that contribute to construct the state of the city, such as "prevalence of petty and/or violent crime" (GLI); "level of corruption and censorship" (GLI) or "friendliness" (CBI).

Direct citizen representation/participation can be observed in the instrumental contribution of interviewer's opinions in the construction of city rankings, as in the case of $\mathrm{CBI}$ - City Brands Index. However, this direct participation is an indirect representation, if representational at all, because in the case of CBI the interviews were applied in 10 countries to assess the image of 50 cities, that do not necessarily coincide with a direct, living experience of the cities included in the ranking. 


\section{Conclusion}

Throughout this reflective exploratory research, we aimed at finding whether city rankings, as assessing and promoting territorial communication tools, take the citizens into account, embedded in the notion of a smart city made by and for the citizens, grounded on communal capital and collective knowledge.

Conclusions point out that, as city representation, city rankings prove to be reductive, frequently misleading, and-although based on citizen status statistics, often collected from publicly available data, tend not to embed citizen participation and insights, thus exposing a representational and participatory gap. We would argue that, in order to effectively represent cities, as they are lived, thought and built by their citizens in their everyday, city rankings must rely in more real-time, updated, people's perception centred data, and embed more citizen participation and insights.

Although generally accepted and widespread through the media as assessing reports of the state of cities, city ranking's value seems to be strategically communicational and enhanced by its news worthy value. City rankings are (and set) opportunity to communicate, therefore can be seen and used more because of their value as promotional tools rather than because of their scientific input relevance.

This does not necessarily question sound scientific procedures in data collection of reputed organisations that contribute to knowledge. Actually, methodological processes within this research were briefly explained but not fully disclosed. Nor was this the main focus of the investigation. Nevertheless, more transparency and accountability of city ranking promoters might add to trust and credibility and more trans-disciplinary teams might enrich the insight and scope of city rankings.

Rather paradoxically, it seems to be not mainly the methodological design, but the use that is made of city rankings that puts city rankings at stake.

It is commonly accepted that city rankings contribute to construct meaning and add value to the cities, enhancing performance and competition. Notwithstanding we found that incomparable, out-dated or poor data that is simplified for the sake of understanding, measuring and controlling territorial realities, serves frequently as ground for assessment, thus establishing a rhetorical construct that does not mirror reality but a propagated through the media and commonly accepted narrative. Categories are a form of simplification and aggregation of complex data in order to make it intelligible, usable and meaningful. From all parameters of the present research this is the one where the strategic intentions of the city ranking producers might be more evident, as setting categories is an immediate form of interpreting reality, and therefore an attempt to control it, not necessarily to assess it.

Furthermore, the political economy of city rankings must be considered when assessing city rankings. Studying data costs money and the three cases we studied are designed and promoted by private organizations, however reputed, with their own agenda. Therefore, as powerful medicines, city rankings should be used with care and critical insight.

A final note on the limitations of the present reflection, based on an exploratory research: we believe further and larger scope investigation might produce different results. Next steps in research would go through more specific rankings and criteria, eventually to direct citizen perceptions — such as liveability, sustainability or happiness — and 
participation - such as activism, political involvement, direct deliberation. Both directions might produce a city ranking that reflects a city as it is lived and idealised by the citizens.

\section{References}

Abadi, M.: The 10 most livable cities in the world in 2018, 25 August 2018. Business Insider. https://www.businessinsider.nl/most-livable-cities-in-the-world-2018-8/

Anholt, S.: Competitive Identity: The New Brand Management for Nations, Cities and Regions. Palgrave Macmillan, Basingstoke (2007)

Atlee, T.: Participatory Sustainability - Notes for an Emerging Field of Civilizational Engagement. CreateSpace, Co-Inteligence Institute, Eugene (2017)

Atlee, T.: The Tao of Democracy: Using Co-Intelligence to Create a World That Works for All. North Atlantic Books, Berkeley (2014)

Atlee, T.: Empowering Public Wisdom: A Practical Vision of Citizen-Led Politics, vol. 4. North Atlantic Books, Berkeley (2012)

Buhmann, A., Ingenhoff, D., White, C., Kiousis, S.: Charting the landscape in research on country image, reputation, brand, and identity. In: Ingenhoff, D., White, C., Buhmann, A., Kiousis, S. (eds.) Bridging Disciplinary Perspectives of Country Image, Reputation, Brand, and Identity, pp. 1-10. Routledge, New York (2019)

Cabannes, Y.: Another City is Possible with Participatory Budgeting. University of Chicago Press Economics Books, Chicago (2019)

https://placebrandobserver.com/smart-cities-how-ict-impacts-urban-developmentrepresentation/

Cardullo, P., Kitchin, R.: Being a 'citizen' in the smart city: up and down the scaffold of smart citizen participation in Dublin, Ireland. GeoJournal 84(1), 1-13 (2019). https://doi.org/10.1007/ s10708-018-9845-8

Casanova, M., Renner, M., Bielenstein, T.: Ranking of the Rankings, Rating the Rankings, in Branding Institute CMR homepage (2018) https://www.branding-institute.com/rating-therankings/ranking-of-the-rankings. Accessed 30 July 2019

Chourabi, H., et al.: Understanding smart cities: an integrative framework. In: 45th Hawaii International Conference on System Sciences, 4-7 January 2012. IEEE (2012)

Dameri, R.P.: Searching for smart city definition: a comprehensive proposal. Int. J. Comput. Technol. 11(5), 2544-2551 (2013)

Drucker, S., Gumpert, G.: The communicative City Redux, international. J. Commun. 10(2016), 1366-1387 (2016)

EIU: The Global Liveability Index 2018 A free overview, Economist Intelligence Unit (2018). http://www.eiu.com/Handlers/WhitepaperHandler.ashx?fi=The_Global_Liveability_ index_2018.pdf\&mode=wp\&campaignid=Liveability2018. Accessed 12 Aug 2019

Giffinger, R., Haindlmaier, G., Kramar, H.: The role of rankings in growing city competition. Urban Res. Pract. 3(3), 299-312 (2010)

Hollands, R.G.: Will the real smart city please stand up? Intelligent, progressive or entrepreneurial? City 12(3), 303-320 (2008). https://doi.org/10.1080/13604810802479126

Ingenhoff, D., White, C., Buhmann, A., Kiousis, S. (eds.): Bridging Disciplinary Perspectives of Country Image, Reputation, Brand, and Identity. Routledge, New York (2019)

Kavaratzis, M.: City Branding. In: The Wiley Blackwell Encyclopedia of Urban and Regional Studies, pp. 1-4 (2019)

Kavaratzis, M., Kalandides, A.: Rethinking the place brand: the interactive formation of place brands and the role of participatory place branding. Environ. Plan. A 47(6), 1368-1382 (2015) 
Kirchener, C.: Paris continues its reign as highest-rated city, Press Release, 30 January 2018. Anholt-GfK (2018). https://www.gfk.com/fileadmin/user_upload/dyna_content/Global/ documents/Press_Releases/2018/20180130_PM_CBI_2017_efin.pdf. Accessed 3 Aug 2019

Maddox, T.: Smart cities: a cheat sheet, TechRepublic, Innovation, 16 July 2018. https://www. techrepublic.com/article/smart-cities-the-smart-persons-guide/. Accessed 3 Aug 2019

Marsal-Llacuna, M.L., Colomer-Llinàs, J., Meléndez-Frigola J.: Lessons in urban monitoring taken from sustainable and livable cities to better address the Smart Cities initiative. Technol. Forecast. Soc. Chang. 90(Part B), 611-622 (2015). https://www.sciencedirect.com/sdfe/reader/ pii/S0040162514000456/pdf. Accessed 16 Aug 2019 (2015)

Marshall, A.: The Top 6 Reasons to Be Wary of City Rankings, Ranked, CityLab 20 May 2015 (2015). https://www.citylab.com/life/2015/05/the-top-6-reasons-to-be-wary-of-city-rankings/ 393686/. Accessed 14 Aug 2019

Martin, C.J., Evans, J., Karvonen, A.: Smart and sustainable? Five tensions in the visions and practices of the smart-sustainable city in Europe and North America. Technol. Forecast. Soc. Chang. 133, 269-278 (2018)

McArthur, J., Robin, E.: Victims of their own (definition of) success: urban discourse and expert knowledge production in the Liveable City. Urban Stud. 56(9), 1711-1728 (2019)

Meijering, J.V., Kern, K., Tobi, H.: Identifying the methodological characteristics of European green city rankings. Ecol. Indic 43, 132-142 (2014)

Melo, A.D.: A Marca dos Cidadãos: Intervenção, Ocupação e Subversão na Paisagem Publicitária Urbana. In: Pires , H., Mesquita, F. (eds.) Publi-Cidade e Comunicação visual urbana, pp. 61-89. CECS, Braga (2018)

Melo, A.D.: "Somos todos smart?": co-inteligência, comunicação e sustentabilidade territorial. In: Abreu, J. (ed.) Inteligência Territorial - Governança, Sustentabilidade e Transparência, Idioteque (2019)

Merkelsen, H., Rasmussen, R.K.: Evaluation of nation brand indexes. In: Ingenhoff, D., White, C., Buhmann, A., Kiousis, S. (eds.) Bridging Disciplinary Perspectives of Country Image, Reputation, Brand, and Identity, pp. 69-84. Routledge, New York (2019)

Newburry, W., Song, M.: Nation branding, product-country images, and country rankings. In: Ingenhoff, D., White, C., Buhmann, A., Kiousis, S. (eds.) Bridging Disciplinary Perspectives of Country Image, Reputation, Brand, and Identity, pp. 49-68. Routledge, New York (2019)

O' Sullivan, F.: Death to Livability! CityLab, 26 June 2019 (2019). https://www.citylab.com/ life/2019/06/best-cities-to-live-list-monocle-ranking-zurich-vienna/592492/. Accessed 14 Aug 2019

Okulicz-Kozaryn, A.: City life: rankings (livability) versus perceptions (satisfaction). Soc. Indic. Res. 110(2), 433-451 (2013)

Papp-Váry, Á.: The Anholt-GMI city brand hexagon and the saffron European city brand barometer: a comparative study. Reg. Bus. Stud. 3(Suppl 1), 555-562 (2011)

Peterson, E.R., Hales, M., Peña, A.M., Dessibourg-Freer, N.: 2018 Global Cities Report - Learning from the East: Insights from China's Urban Success. A. T. Kearney (2018)

Rizzon, F., Bertelli, J., Matte, J., Graebin, R.E., Macke, J.: Smart City: um conceito em construção. Revista Metropolitana de Sustentabilidade 7(3), 123-142 (2017). ISSN 2318-3233

Rozek, J., Giles-Corti, B., Gunn, L.: The world's 'most liveable city' title isn't a measure of the things most of us actually care about, The Conversation Trust (UK) Limited, August 15, 2018 7.18am BST (2018). http://theconversation.com/the-worlds-most-liveable-city-title-isnta-measure-of-the-things-most-of-us-actually-care-about-101525. Acceded 20 Aug 2019

Stremtan, F.: Some consideration regarding collective intelligence. In: 6th Annual International Conference of Territorial Intelligence, "Tools and Methods of Territorial Intelligence", p. 10, October 2008

Vanolo, A.: Smartmentality: the smart city as disciplinary strategy. Urban Stud. 51(5), 883-898 (2014) 
Yigitcanlar, Tan, Inkinen, Tommi: Benchmarking City Performance. Geographies of Disruption, pp. 159-197. Springer, Cham (2019). https://doi.org/10.1007/978-3-030-03207-4_12

Zhang, F., et al.: Privacy-aware smart city: a case study in collaborative filtering recommender systems. J. Parallel Distrib. Comput. 127, 145-159 (2019) 